\title{
Haversine Formula Implementation to Determine Bandung City School Zoning Using Android Based Location Based Service
}

\author{
Undang Syaripudin ${ }^{1}$, Niko Ahmad Fauzi², Wisnu Uriawan ${ }^{3}$, \\ Wildan Budiawan $Z^{4}$, Ali Rahman ${ }^{5}$ \\ \{undang_if@uinsgd.ac.id ${ }^{1}$,nikoaf@yahoo.co.id ${ }^{2}$,wisnu_u@uinsgd.ac.id ${ }^{3}$, wildan.b@uinsgd.ac.id ${ }^{4}$, \\ ali@uinsgd.ac.id ${ }^{5\}}$
}

Department of Informatics, UIN Sunan Gunung Djati Bandung ${ }^{1,2,3,4,5}$

\begin{abstract}
The spread of schools in Bandung city, make the parents have difficulties choose which school is the nearest from the house. Therefore, when the children will go to school the just can go by foot. So, the purpose of this research is to make an application to determined the closest school based on zonation system using Haversine Formula as the calculation of the distance between school position with the house, and Location Based Service as the service to pointed the early position using Global Positioning System (GPS). The result of the research show that the accuracy of this calculation reaches $98 \%$ by comparing the default calculations from Google. Haversine Formula is very suitable to be applied in this research with the results which are not much different.
\end{abstract}

Keywords: Global Positioning System (GPS), Bandung City, Haversine Formula, Location Based Service, zonation system, Rational Unified Process (RUP), PPDB

\section{Introduction}

Starting in 2017, the Ministry of Education and Culture implements a zoning system for each school valid from elementary to high school/ vocational school. This zoning system aims to equalize the right to obtain education for school-age students. The PPDB revenue system is no longer based on academic achievement, but based on the distance of the student's residence with the school (zoning). Students in certain school zones must be accepted, must not be rejected. So, the PPDB zoning rules make students get the closest education service from their home or residence. Education dan Cultural Ministry hopes that there will be no longer school schooling, no favorite schools and suburban schools. All schools are the same. Students in the same area come from poor families and mediocre will gather with rich and smart students in the same school [1].

Science and technology are currently growing rapidly, especially in the field of computers. The increasingly sophisticated use of computers fosters a special attraction for users, one of which is information technology. The influence and role of IT on human life is very important. The development of information technology is now developing along with the development of human development[2]. The development of information technology can now be accessed without limits of space and time because it is based online. Online information systems are packaged in various forms, one of them is a smartphone application. Information technology 
based on smartphone applications, especially Android, is currently growing rapidly[3]. Android-based information technology allows the delivery of information faster, interactive and interesting in just one hand. So it is not surprising if Android is one of the most used Operating Systems by usersand can be found and downloaded the application via the playstore[4].

Along with the continued development of Android-based smartphones, many developers have made various kinds of applications, such as information system-based applications, chat, social media, games, and so on. These applications are intended to facilitate users in their daily activities, for example sending messages to relatives, seeing various information around, releasing fatigue, and so on. So, various Android-based applications have been very much found that can be used for everyday needs. The community's need for information, especially in the search sector of nearby places is very high. No wonder because users want to know the location of certain places close to him, such as when searching for gas stations, mosques, public toilets, ATM machines, banks, hospitals, police stations, schools and others. Some information system applications often display in the form of maps / maps to make it easier for users to find the desired location with the Location Based Service (LBS) method. Location Based Service itself is an information service that can be accessed with a mobile device through a network and is able to display the geographical position of the existence of the mobile device. So, a locationbased information system if integrated with LBS, then the delivery of information will be much more interactive and interesting. Location based services are service based location or general term that is often used to describe the technology used to find the location of the device the user is using. This service uses global positioning service (GPS) and cell-based location technology from Google[5].

Every year the school carries out New Student Admission (PPDB). Many rules are implemented by the government to support smooth implementation of PPDB. The PPDB is implemented to support the sustainability of schools in the future. All schools want the implementation of PPDB to receive students who are in accordance with the existing quota [1]. School institutions include many primary and secondary schools in the city of Bandung. Users who want to know the location of the existence of the school based on zoning from their original position cannot possibly remember all at once. Based on data on the Bandung City Education Office Website, there are a total of 331 public school institutions (274 elementary schools and 57 junior high schools) spread across Bandung. So that a nearby school-based information search system based on zoning is suitable if using Haversine Formula and Location Based Service, where the distance between the user and the school will be calculated based on zoning.

\section{Methodology}

\section{1) Zoning System}

According to the KBBI zoning is the division or division of an area into several parts, in accordance with the functions and management objectives. Zone is an area or area that has specific environmental functions and characteristics. Zoning regulations / zoning regulations are provisions that govern zone classification, further regulation regarding land use, and procedures for implementing development. A zone has uniform rules (land use, intensity, and building mass), one zone with another zone can be different sizes and rules [1]. In the previous hardly any years, the standards of zoning, or the meaning of land catchment regions for the enrollment of understudies to specific schools, have pulled in distinct fascination 
from altogether different perspectives. From one viewpoint, zoning has gone under assault for subverting the job of parental decision, or the opportunity of guardians to figure out which school their kids ought to join in [6]. The zoning system is a new student acceptance system based on the radius or distance of prospective students and the intended school. The reference in determining the distance is determined from the coordinates of the house to the school coordinate point. The advantages of this zoning system are as follows:

a) Equitable education.

b) More time-saving because school is close.

c) More efficient transportation costs.

d) The condition of students is more fit.

e) Reducing congestion.

Through the zoning system, it is expected that all citizens of the city of Bandung can get education that is located close to where they live.

\section{2) Haversine Formula}

Haversine Formula is a significant condition in the field of route, to discover the circular segment separation between two focuses on a ball from scope and longitude [7][8]. This is an extraordinary type of conditions from circular trigonometry, the law of haversines, searching for the relationship of sides and edges to triangles in the circle. Haversine Formula is a technique for knowing separation between two focuses by figuring that the earth is certainly not a level plane yet is a field that has a level of arch.

Haversine Formula was utilized to establish closest potential spot point with the starting point position and goal point, the haversine recipe is a condition giving incredible hover removes between two focuses on a circle from their longitudes and scopes [9].

\section{3) Location Based Service (LBS)}

Area Based Service is a help that is capacity to look with Global Positioning Service (GPS) innovation and Google's cell-based area. Guide and area based administrations use scope and longitude to decide geographic area, yet as a client we need our realtime address or position not the estimation of scope and longitude[10]. Advanced guide can be shown in two dimensional with the utilization of scope and longitude, this is an important apparatus to show the situation of a district dependent on its unique position. Innovation has been grown fastly, it is shown with the mainstream innovation that known as Location Based Services (LBS) which is innovation to acquire a position geologically presence of cell phones, for example, cell phone [11]. Location Based Service (LBS) or location-based service is an information service that can be accessed through a network from mobile devices and can display the geographic position of the mobile device's existence. The main elements of Location Based Service are two, namely:

a) Location Manager (API Maps): Provides tools for sources or sources for LBS, Application Programming Interface (API) Maps provides facilities for displaying or manipulating maps. This package is on "com.google.android.maps;".

b) Location Providers (API Location): Provides location search technology used by the device. API Location is related to GPS (Global Positioning System) data and real-time location data. API Location is in the Android package, which is in the "android.location" package. Location, displacement, and proximity to a particular location can be determined through the Location Manager.

There are five main supporting components in Location-Based Services technology, including: 
a) Mobile device, is one of the important components in LBS. This tool functions as a tool for users to request information. The results of the information requested can be text, sound, images and so on. Mobile devices that can be used can be PDAs, smartphones, laptops. In addition, mobile devices can also function as navigation tools in vehicles such as GPS-based navigation devices.

b) Communication Network, this component functions as a connecting line that can send data sent by users of mobile devices to then be sent to service providers and then the results of the request are sent back by the service provider to the user.

c) Positioning Components (Position Indicators / Locations), Each service provided by a service provider will usually be based on the position of the user requesting the service. Therefore we need a component that functions as a processor / processor that will determine the position of the service user at that time. The user's position can be obtained through mobile communication networks or also using the Global Positioning System (GPS).

d) Service providers and applications, are components of LBS that provide a variety of services that can be used by users. For example, when a user requests a service to know his current position, the application and service provider directly processes the request, starting from calculating and determining the position of the user, finding the route, searching for data in the Yellow Pages according to demand, and many others.

e) Data and content providers, service providers do not always store all data and information that they process. Because it can be a variety of data and information processed that comes from developers / third parties who do have the authority to store it. For example, geographic databases and locations may come from government-owned bodies or also company / business / industry data can come from the Yellow Pages, as well as other data provider companies.

The methodology of this research consists of two stages, including the data collection stage and the system development stage.

1) Data Collection Phase

- Observation and Interview

Where at this stage is done by collecting data, where data has relevance to the problems being studied directly.

- $\quad$ Studies Literature

Where at this stage is done by describing the data obtained from various reference sources related to the problems being studied, to then be analyzed, and described in the form of a description that the dilator behind the existence of concepts and theories expressed in the theoretical foundation.

- Internet

Where at this stage is done by looking for reading sources related to the problems being studied online.

2) Stage of System Development

This stage, system development using the RUP (Rational Unified Process) method. This model was chosen because it focuses on developing models using UML (Unified Model Language). RUP gives a trained methodology on the best way to allot assignments and obligations inside the product advancement process. It comprises of nine procedure work processes (business displaying, necessities, investigation and plan, execution, test, sending, setup the board, venture the executives, and condition) [12]. 


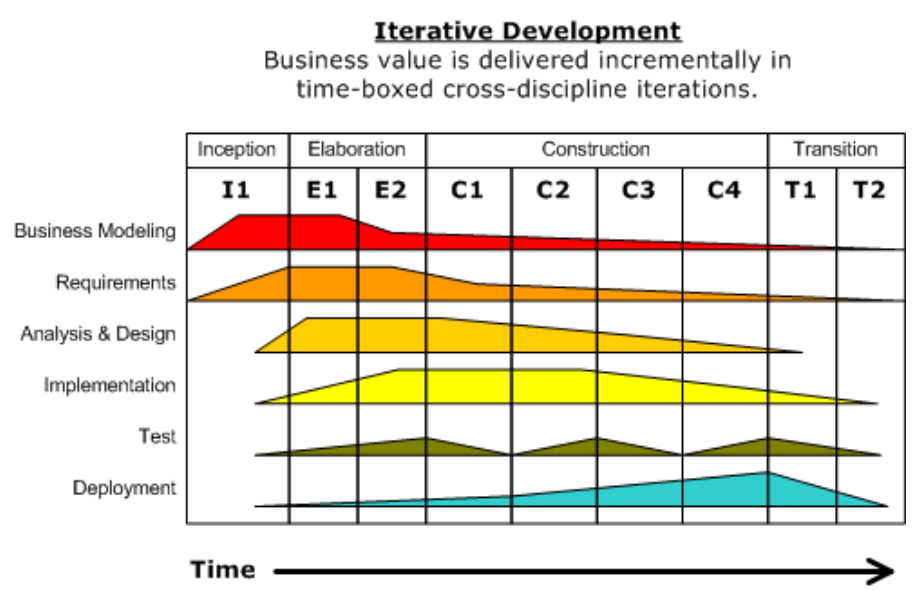

Fig. 1 The RUP Software Development Life Cycle [13][12][14]

Information investigation strategies in making programming utilize the RUP (Rational Unified Process) advancement technique, which incorporates a few stages including:

a) Inception

This stage set the scope of application, perform functional requirements analysis, interface requirements analysis, hardware requirements analysis, and soft needs analysis.

b) Elaboration

This stage make the design of subsystem architecture (architecture pattern), application database design, interface design / application display, and UML diagram modeling.

c) Construction

This stage is the stage for implementing design results. Determination of coding patterns used, program making, testing, program optimization, data collection of various possibilities for further development / improvement.

d) Transition

Submit software to the user, test it in the user's place, and correct problems that arise when and after testing. 


\section{Results and Discussions}

1) Design of System Flow

Design modeling is needed for the needs and activities that occur in the application, so that the implementation of the application can run well. The design of this application will be explained in the Use Case Diagram below:

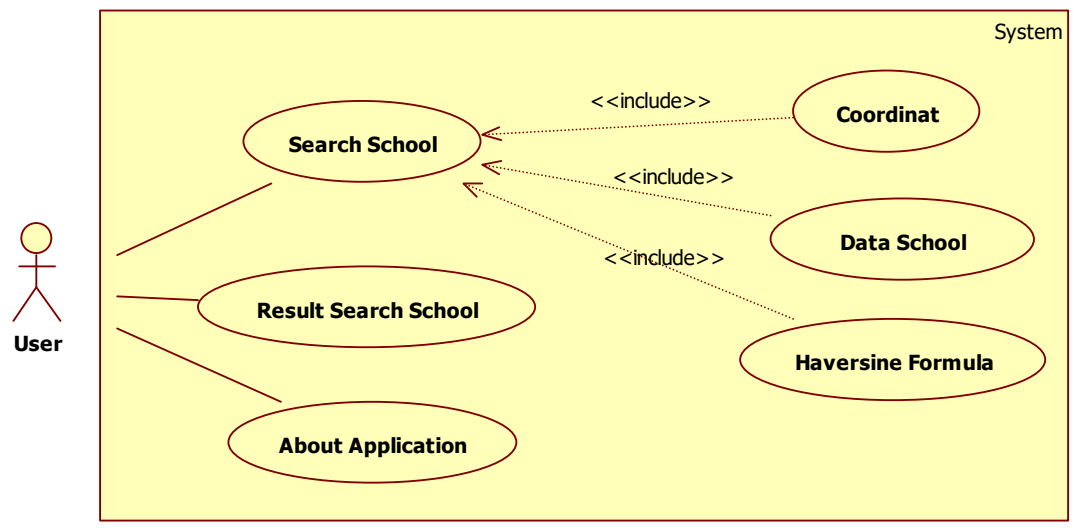

Fig. 2 Use Case Diagram

From the picture above shows the interaction between actors / users with the system, including school searches with include coordinates, school data and haversine formulas, school search results and about applications.

\section{2) Haversine Formula Analysis}

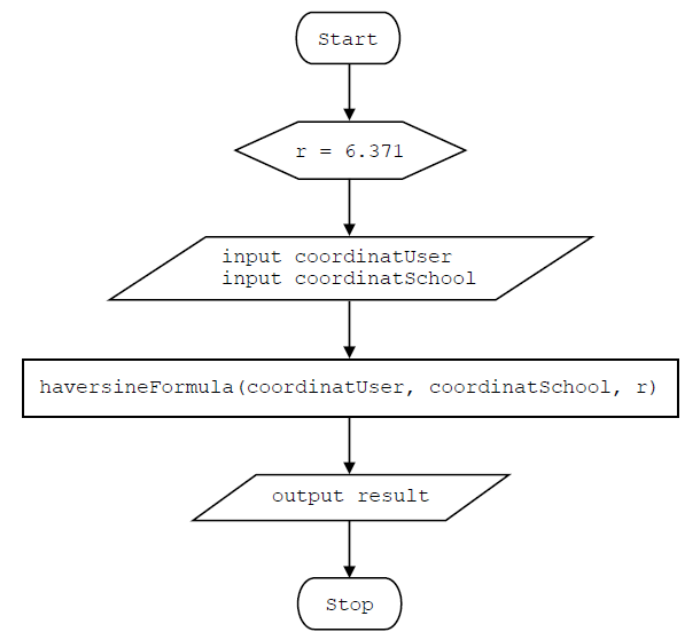

Fig. 3 Flowchart haversine formula 
The flowchart above explains the workflow of haversine formula. Beginning with the value $r$ which means the radius of the earth. Next is the coordinatUser input (user coordinates) and coordinatSchool input (school coordinates). Then if it is fulfilled it will be calculated and produce the output result in units of kilometers. Assuming that the earth is perfectly round with radius $(\mathrm{r})=6,371 \mathrm{~km}$, and the location of two points in the sphere coordinates (latitude and longitude) are lat1, $\operatorname{lng} 1$, and lat2, respectively, then the Haversine Formula formula can be written with the equation as follows [15]:

$$
\begin{aligned}
& \mathrm{x}=(\operatorname{lng} 2-\operatorname{lng} 1) * \cos ((\text { lat } 1+\operatorname{lat} 2) / 2) \\
& \mathrm{y}=(\operatorname{lat} 2-\operatorname{lat} 1) \\
& \mathrm{d}=\operatorname{sqrt}(\mathrm{x} * \mathrm{x}+\mathrm{y} * \mathrm{y}) * \mathrm{r}
\end{aligned}
$$

Information:

$\mathrm{x}=$ longitude (latitude)

$\mathrm{y}=$ latitude (longitude)

$\mathrm{d}=$ distance

$\mathrm{r}=$ earth radius $(6371 \mathrm{~km})$

1 degree $=0.0174532925$ radians

Research Result

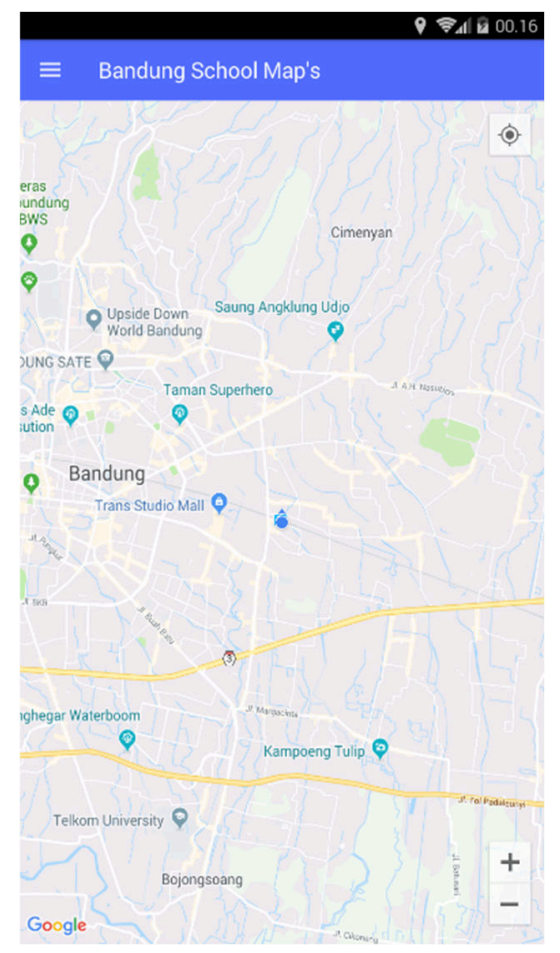

Fig. 4 view main page 
In the picture above is the main view of the application. In this main view, it displays a map from the Google API and in the middle in the form of a blue dot is the coordinates of the user which is an implementation of Location Based Service.

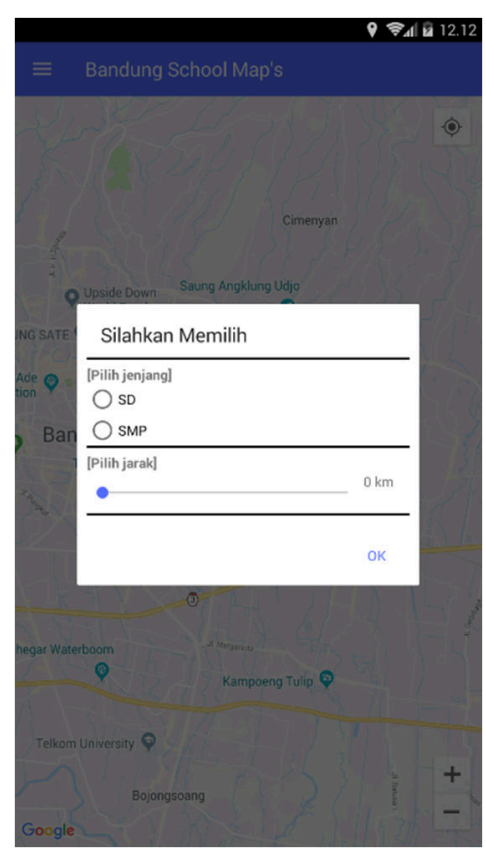

Fig. 5 view menu search school

In the picture above is a display when you want to do a school search. In the display, there are 2 levels of choice, namely Sekolah Dasar (SD) and Sekolah Menengah Pertama (SMP) and are also provided with distance seekers ranging from 0 to $10 \mathrm{~km}$.

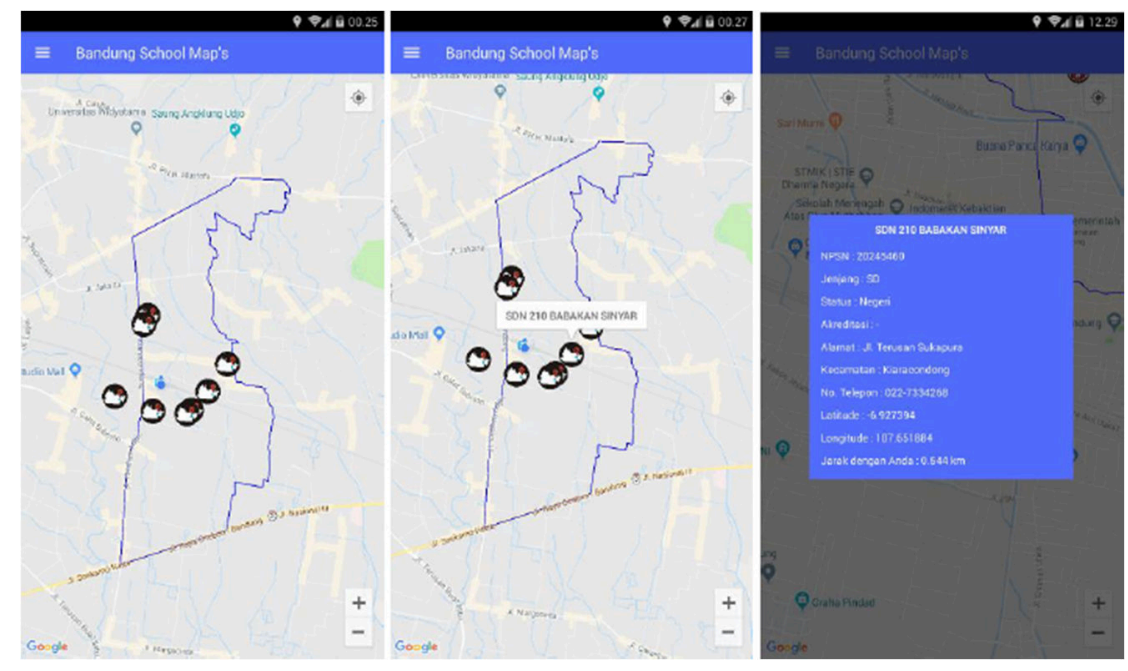

Fig. 6 view result search school 
In the picture above is the search result of the calculation process of haversine formula. The search results will show the school points that have previously been set based on the distance range that will be displayed on the map. When the marker is clicked, a school name will appear, and when the school name is clicked, full information will appear from the school. Result Test System

Based on data collection that has been done, sensitivity testing must also be done on the data that has been obtained, whether the system or application can run according to the study or not. In this test the system will be given 30 sample data where each of the coordinates has a different value. This test is intended to measure the accuracy of the formula haversine formula with a formula from Google Maps (google distance) approaching the same or not.

Table. 1 Accuracy Testing

\begin{tabular}{|c|c|c|c|}
\hline No & Koordinat 1 & Koordinat 2 & Akurasi \\
\hline 1 & $\begin{array}{l}\text { Lat }=-6.924961 \\
\text { Lng }=107.646213\end{array}$ & $\begin{array}{l}\text { Lat }=-6.927394 \\
\text { Lng }=107.651884\end{array}$ & $99,0001467 \%$ \\
\hline 2 & $\begin{array}{l}\text { Lat }=-6.913711 \\
\text { Lng }=107.577663\end{array}$ & $\begin{array}{l}\mathrm{Lat}=-6.922897 \\
\mathrm{Lng}=107.576048\end{array}$ & $98,9941748 \%$ \\
\hline 3 & $\begin{array}{l}\text { Lat }=-6.917417 \\
\mathrm{Lng}=107.661200\end{array}$ & $\begin{array}{l}\mathrm{Lat}=-6.919457 \\
\mathrm{Lng}=107.655785\end{array}$ & $99,0003439 \%$ \\
\hline 4 & $\begin{array}{l}\text { Lat }=-6.914642 \\
\text { Lng }=107.677048\end{array}$ & $\begin{array}{l}\text { Lat }=-6.919079 \\
\text { Lng }=107.680822\end{array}$ & $99,0031056 \%$ \\
\hline 5 & $\begin{array}{l}\text { Lat }=-6.937139 \\
\text { Lng }=107.601256\end{array}$ & $\begin{array}{l}\text { Lat }=-6.938114 \\
\mathrm{Lng}=107.603355\end{array}$ & $98,9999609 \%$ \\
\hline$\cdots$ & & …… & 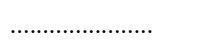 \\
\hline 24 & $\begin{array}{l}\text { Lat }=-6.926254 \\
\text { Lng }=107.705227\end{array}$ & $\begin{array}{l}\text { Lat }=-6.924045 \\
\mathrm{Lng}=107.704971\end{array}$ & $98,9946278 \%$ \\
\hline 25 & $\begin{array}{l}\text { Lat }=-6.950225 \\
\text { Lng }=107.676229\end{array}$ & $\begin{array}{l}\text { Lat }=-6.946662 \\
\text { Lng }=107.676508\end{array}$ & $98,9945797 \%$ \\
\hline 26 & $\begin{array}{l}\text { Lat }=-6.937676 \\
\text { Lng }=107.609425\end{array}$ & $\begin{array}{l}\text { Lat }=-6.938114 \\
\text { Lng }=107.603355\end{array}$ & $99,0011301 \%$ \\
\hline 27 & $\begin{array}{l}\mathrm{Lat}=-6.888282 \\
\mathrm{Lng}=107.588060\end{array}$ & $\begin{array}{l}\text { Lat }=-6.8880768 \\
\text { Lng }=107.582197\end{array}$ & $99,001157 \%$ \\
\hline 28 & $\begin{array}{l}\text { Lat }=-6.868354 \\
\mathrm{Lng}=107.585916\end{array}$ & $\begin{array}{l}\text { Lat }=-6.869352 \\
\text { Lng }=107.58851\end{array}$ & $99,0003251 \%$ \\
\hline 29 & $\begin{array}{l}\mathrm{Lat}=-6.915941 \\
\mathrm{Lng}=107.618385\end{array}$ & $\begin{array}{l}\text { Lat }=-6.921043 \\
\text { Lng }=107.61521\end{array}$ & $98,9963841 \%$ \\
\hline 30 & $\begin{array}{l}\mathrm{Lat}=-6.910140 \\
\mathrm{Lng}=107.703556\end{array}$ & $\begin{array}{l}\mathrm{Lat}=-6.908829 \\
\mathrm{Lng}=107.702187\end{array}$ & $98,9981668 \%$ \\
\hline
\end{tabular}

From the Accuracy Test Table above, it can be explained that every 1 time calculation between google distance and haversine formula produces an accuracy rate of $98 \%$, meaning that the results of calculations using haversine formula are almost close to the exact calculation using Google's default distance from Google. 


\section{Conclusions}

After going through the stages in accordance with the RUP (Rational Unified Process) software development method in the construction of this application, we can conclude a number of things as follows:

a) The use of the Location Based Service method and the Haversine Formula formula in the search for the nearest school based on the zoning system has been successfully implemented. But not always these calculations are accurate because this application depends on the accuracy of the GPS on each headphone device used.

b) After testing 30 samples of the formula haversine formula with google distance, the accuracy value of $98 \%$ is obtained, indicating that the calculation using haversine formula is almost close to the exact same when compared with the calculation using the default Google distance from Google.

\section{Acknowledgments}

We might want to give affirmation for Research and Publication Center of UIN Sunan Gunung Djati Bandung that give the full help and reserve for this distribution research.

\section{References}

[1] Dewi K E and Septiana R 2018 Evaluation of Zoning Student Recruitment System in Year 2018 Proceeding Int. Semin. Educ. Innov. Issues Challenges Educ. Educ. Sustain. Univ. Sarjanawiyata Tamansiswa. 109-15

[2] Sri Utami S 2010 Pengaruh Teknologi Informasi dalam Perkembangan Bisnis J. Akunt. dan Sist. Teknol. Inf. 61-7

[3] Hardiansyah A 2018 Designing Android Based Augmented Reality Location-Based Service Application J. Online Inform. 2110

[4] Fauzi A, Pernando F and Raharjo M 2018 Penerapan Metode Haversine Formula Pada Aplikasi Pencarian Lokasi Tempat Tambal Ban Kendaraan Bermotor Berbasis Mobile Android J. Tek. Komput. 4 $56-63$

[5] Agus Adhi Sumitro, Alicia A. E. Sinsuw X B N N 2017 Implementasi Location Based Service untuk Aplikasi Mobile City Directory Studi Kasus Kota Kotamobagu J. Tek. Inform. Univ. Sam Ratulangi 11

[6] McCulloch G 1991 School zoning, equity and freedom: The case of new zealand J. Educ. Policy 6 155-68

[7] Chopde N and Nichat M 2013 Landmark Based Shortest Path Detection by Using Dijkestra Algorithm and Haversine Formula Int. J. Eng. Res. Appl. 3 162-5

[8] Putra R H D, Sujiani H and Safriadi N 2015 Penerapan Metode Haversine Formula Pada Sistem Informasi Geografis Pengukuran Luas Tanah J. Sist. dan Teknol. Inf. 1 1262-70

[9] Priandani N D, Tolle H and Yunianto D R 2016 Design and implementation of mobile-based application for Malang City public transportation route search Int. J. Adv. Soft Comput. its Appl. 8 48-58

[10] Rompas, B. R, A. A. E. Sinsuw, S. R. U. A.Sompie A S M L 2014 Pemetaan Location Based Service

(Lbs) Wisata Bengkulu Berbasis Android J. Media Infotama 10 1-11

[11] Alam C N, Manaf K, Atmadja A R and Aurum D K 2016 Implementation of haversine formula for counting event visitor in the radius based on Android application 2016 4th International Conference on Cyber and IT Service Management pp 1-6

[12] Mohd H, Robie M A M, Baharom F, Darus N M, Saip M A and Yasin A 2016 Adapting Rational 
Unified Process (RUP) approach in designing a secure e-Tendering model AIP Conf. Proc. 1761

[13] Anwar A 2014 A Review of RUP (Rational Unified Process) Int. J. Softw. Eng. 5 8-24

[14] Rational 1998 Rational Unified Process: Best Practices for Software Development Teams Ration. Softw. white Pap. TP026B 21

[15] Arfiani I and Normawati D 2018 Penerapan Haversine Formula Pada Server Aplikasi Location Based Service Untuk Pencarian 7-12 